\title{
The Impact of Body Mass Index and Waist Circumference on Health-related Quality of Life Among Colorectal Cancer Survivors
}

Citation for published version (APA):

Vissers, P. A. J., Martucci, R. B., Mols, F., Bours, M. J. L., Winkels, R. M., Kampman, E., Weijenberg, M. P., van de Poll-Franse, L. V., \& Beijer, S. (2017). The Impact of Body Mass Index and Waist Circumference on Health-related Quality of Life Among Colorectal Cancer Survivors: Results from the PROFILES Registry. Nutrition and Cancer-An International Journal, 69(8), 1177-1184. https://doi.org/10.1080/01635581.2017.1367938

Document status and date:

Published: 01/01/2017

DOI:

10.1080/01635581.2017.1367938

Document Version:

Publisher's PDF, also known as Version of record

Document license:

Taverne

Please check the document version of this publication:

- A submitted manuscript is the version of the article upon submission and before peer-review. There can be important differences between the submitted version and the official published version of record.

People interested in the research are advised to contact the author for the final version of the publication, or visit the DOI to the publisher's website.

- The final author version and the galley proof are versions of the publication after peer review.

- The final published version features the final layout of the paper including the volume, issue and page numbers.

Link to publication

\footnotetext{
General rights rights.

- You may freely distribute the URL identifying the publication in the public portal. please follow below link for the End User Agreement:

www.umlib.nl/taverne-license

Take down policy

If you believe that this document breaches copyright please contact us at:

repository@maastrichtuniversity.nl

providing details and we will investigate your claim.
}

Copyright and moral rights for the publications made accessible in the public portal are retained by the authors and/or other copyright owners and it is a condition of accessing publications that users recognise and abide by the legal requirements associated with these

- Users may download and print one copy of any publication from the public portal for the purpose of private study or research.

- You may not further distribute the material or use it for any profit-making activity or commercial gain

If the publication is distributed under the terms of Article $25 \mathrm{fa}$ of the Dutch Copyright Act, indicated by the "Taverne" license above, 


\section{The Impact of Body Mass Index and Waist Circumference on Health-related Quality of Life Among Colorectal Cancer Survivors: Results from the PROFILES Registry}

Pauline A. J. Vissers, Renata B. Martucci, Floortje Mols, Martijn J. L. Bours, Renate M. Winkels, Ellen Kampman, Matty P. Weijenberg, Lonneke V. van de Poll-Franse \& Sandra Beijer

To cite this article: Pauline A. J. Vissers, Renata B. Martucci, Floortje Mols, Martijn J. L. Bours, Renate M. Winkels, Ellen Kampman, Matty P. Weijenberg, Lonneke V. van de Poll-Franse \& Sandra Beijer (2017) The Impact of Body Mass Index and Waist Circumference on Health-related Quality of Life Among Colorectal Cancer Survivors: Results from the PROFILES Registry, Nutrition and Cancer, 69:8, 1177-1184, DOI: 10.1080/01635581.2017.1367938

To link to this article: https://doi.org/10.1080/01635581.2017.1367938

Published online: 16 Oct 2017.

Џll Article views: 274

View Crossmark data ¿

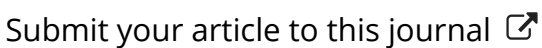




\title{
The Impact of Body Mass Index and Waist Circumference on Health-related Quality of Life Among Colorectal Cancer Survivors: Results from the PROFILES Registry
}

\author{
Pauline A. J. Vissers ${ }^{a}$, Renata B. Martucci ${ }^{\mathrm{b}, c}$, Floortje Mols ${ }^{\mathrm{d}}$, Martijn J. L. Bours ${ }^{\mathrm{e}}$, Renate M. Winkels ${ }^{\mathrm{f}}$, Ellen Kampman ${ }^{\mathrm{f}}$, \\ Matty P. Weijenberg ${ }^{e}$, Lonneke V. van de Poll-Franse ${ }^{a, d, g}$, and Sandra Beijer ${ }^{a}$ \\ ${ }^{a}$ Netherlands Comprehensive Cancer Organisation (IKNL), 3501 DB Utrecht, The Netherlands; ${ }^{b}$ Nutrition and Dietetic Service, Cancer Hospital I, \\ National Cancer Institute, Rio de Janeiro, Brazil; ' Nutrition Institute, State University of Rio de Janeiro, Rio de Janeiro, Brazil; ${ }^{\mathrm{d} C o R P S}-$ Center of \\ Research on Psychology in Somatic Diseases, Department of Medical Psychology and Clinical Psychology, Tilburg University, 5000 LE Tilburg,

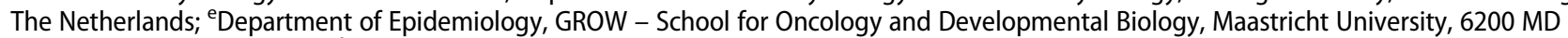 \\ Maastricht, The Netherlands; ' Division of Human Nutrition Wageningen University, 6700 AA Wageningen, The Netherlands; ${ }^{9}$ Division of \\ Psychosocial Research and Epidemiology, Netherlands Cancer Institute, 1006 BE Amsterdam, The Netherlands
}

\begin{abstract}
Background: We aimed to assess the association of waist circumference (WC) and body mass index (BMI) with health-related quality of life (HRQL) among colorectal cancer (CRC) survivors. Methods: CRC survivors diagnosed between 2000 and 2009 completed questionnaires in August 2013 (with self-reported weight, height, and self-assessed WC) and January 2014 (with HRQL using the EORTCQLQ-C30). Clinical characteristics were retrieved from the Netherlands Cancer Registry. In multivariable linear regression analyses associations of BMI only, WC only and both BMI and WC with HRQL outcomes were assessed. Results: 1,111 CRC survivors were included of whom $34 \%$ had a normal weight $\left(18.5 \leq \mathrm{BMl}<25 \mathrm{~kg} / \mathrm{m}^{2}\right), 49 \%$ had overweight $\left(25 \leq \mathrm{BMl}<30 \mathrm{~kg} / \mathrm{m}^{2}\right), 17 \%$ had obesity $\left(\mathrm{BMI} \geq 30 \mathrm{~kg} / \mathrm{m}^{2}\right.$ ), and $44 \%$ had an increased WC (i.e., $>102$ and $>88 \mathrm{~cm}$ for men and women, respectively). Both BMI and WC were separately associated with worse global health status, functioning, and more symptoms of fatigue. Increased WC was associated with lower physical, role and emotional functioning, regardless of BMI, with average differences ranging between 3 and 5 points. Conclusion: Future research on HRQL among CRC survivors should consider both BMI and WC. Furthermore, weight reduction trials should not only focus on general weight loss but also on the loss of abdominal fat.
\end{abstract}

\section{ARTICLE HISTORY}

Received 5 April 2017 Accepted 4 August 2017

\section{Introduction}

Colorectal cancer (CRC) is the third most common cancer in men $(746,000$ incident cases, $10.0 \%$ of all cancer cases) and the second in women (614,000 incident cases, $9.2 \%$ of all cancer cases) and the incidence is still increasing worldwide $(1,2)$. At the same time, mortality has decreased, due to earlier diagnosis and improved therapies, leading to an increase in the prevalence of CRC (3). Because of the high number of CRC survivors, studying health-related quality of life (HRQL) and understanding factors associated with HRQL becomes a major issue.

Several studies have addressed HRQL of long-term ( $\geq 5$ yr) CRC survivors. Two systematic reviews showed that CRC survivors had a good overall HRQL, but may have slightly lower physical functioning and more psychological problems, including depression, anxiety and distress than the general population $(4,5)$. Furthermore, survivors reported to suffer from bowel problems and sexual dysfunction $(4,6)$. Apart from having a stoma and recurrence of the disease, mainly socio-demographic and health-related factors such as age, social network size, income, education, body mass index (BMI) and the number of comorbidities were associated with HRQL $(4,5)$.

BMI is also considered to be associated with HRQL in CRC, but the literature is not conclusive on this matter. A cross-sectional survey showed that obese CRC survivors reported significantly poorer physical functioning and mental health compared with overweight or normal weight CRC survivors (7). Three studies among CRC survivors showed that a higher BMI was associated with worse scores in physical functioning, role functioning, bodily pain, general health, fatigue and vitality (8-10). However, Rodriguez et al. found no association between BMI and physical, mental, and overall quality of life 
among 5- to 7-yr CRC survivors (11). The discrepancy in results might be due to the lack of information about the amount of abdominal fat, which is considered to have more influence on cancer, prognosis and HRQL than BMI (12-14). Waist circumference (WC) has been suggested to be a reliable estimate for abdominal obesity (15). Several studies show that WC is associated with complications after rectal cancer surgery, and a reduced disease specific survival (16-18). However, as far as we know, the association between WC and HRQL among CRC survivors has not been studied yet.

In this study, we therefore aimed to assess the association between WC, BMI and HRQL among long-term CRC survivors. We hypothesized that WC is associated with HRQL outcomes independent of BMI.

\section{Methods}

\section{Setting and Study Population}

Data from a large population-based study among CRC patients were used. All CRC patients diagnosed between January 2000 and June 2009 were sampled from the southern area of the Netherlands Cancer Registry (NCR). The NCR contains clinical data on all newly diagnosed cancer patients in the Netherlands. The southern area comprises 2.4 million inhabitants, 10 hospitals and 2 radiotherapy institutes. After the initial patient selection, the Patient Reported Outcomes Following Initial Treatment and Long term Evaluation of Survivorship (PROFILES) registry was used for the longitudinal patient reported data collection (19). Patients with cognitive impairments, unverifiable addresses and patients who died prior to the study started were excluded from the initial selection. The initial data collection started in 2010. In the current study, we present data regarding weight, height and WC which were collected in August 2013 and data regarding HRQL which were collected in January 2014 (Fig. 1). Ethical approval for the study was obtained from the local certified Medical Ethics Committee of the Maxima Medical Centre Veldhoven. A complete overview of the selection process can be found elsewhere (20). Data from this longitudinal study are (partly) available online for noncommercial scientific research, subject to study question, privacy, and confidentiality restrictions, and registration from PROFILES (www.profilesregistry.nl).

\section{Data Collection}

CRC patients were invited for participation via a letter from their (former) attending physician. The letter included a secured link with login and password to the online questionnaire, or patients could request a paper version of the questionnaire, whichever they preferred. After two months, a reminder with a paper questionnaire was sent. Patients were reassured that nonparticipation had no consequences for their follow-up care or treatment.

\section{Body Composition, Sociodemographic and Clinical Characteristics}

Weight $(\mathrm{kg})$ and height $(\mathrm{cm})$ were self-reported and used to calculate BMI $\left(\mathrm{kg} / \mathrm{m}^{2}\right)$. BMI was categorized as normal

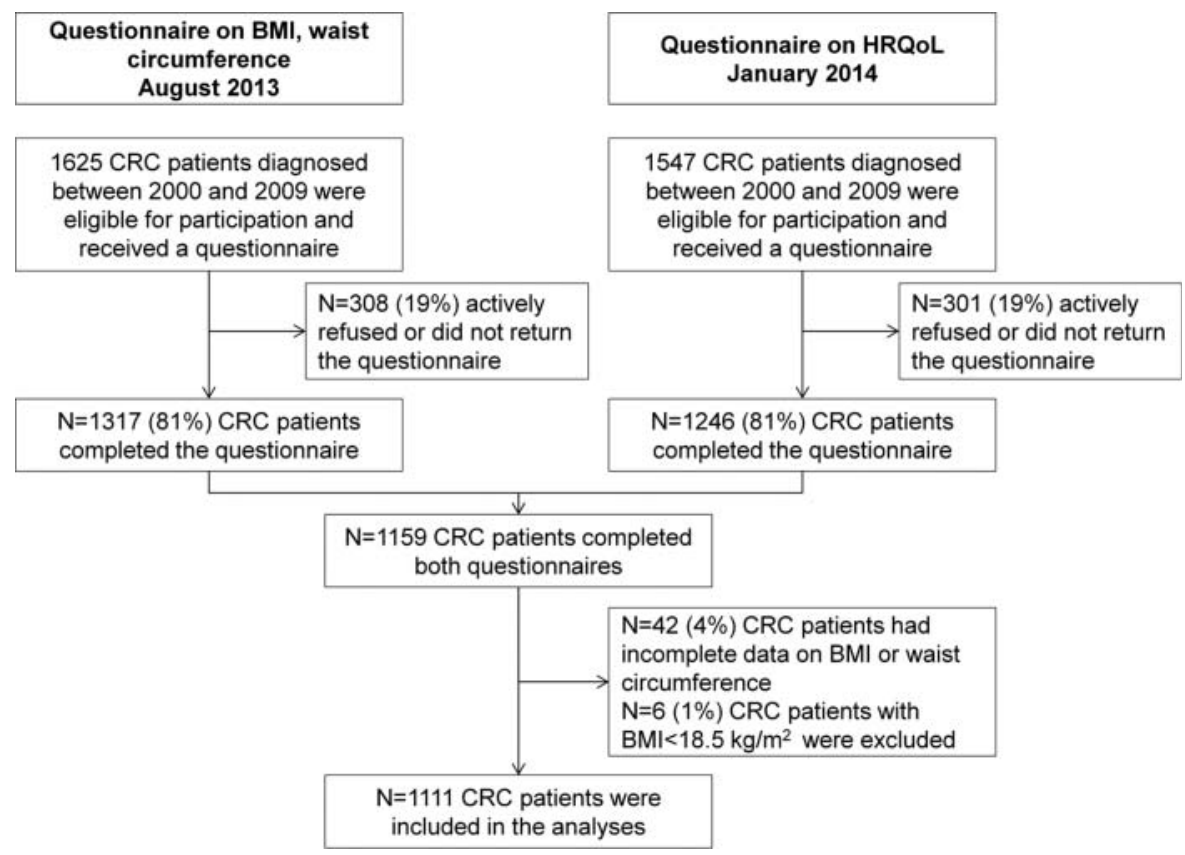

Figure 1. Flowchart of the study population. 
weight $\left(18.5 \leq\right.$ BMI $\left.<25 \mathrm{~kg} / \mathrm{m}^{2}\right)$, overweight $(25 \leq$ BMI $\left.<30 \mathrm{~kg} / \mathrm{m}^{2}\right)$ or obesity $\left(\mathrm{BMI} \geq 30 \mathrm{~kg} / \mathrm{m}^{2}\right)$. Patients with underweight $\left(\mathrm{BMI}<18.5 \mathrm{~kg} / \mathrm{m}^{2}\right)$ were excluded. A measuring tape was provided with the questionnaire and patients were instructed to measure their WC (narrowest circumference of the waist), while standing, without bulky clothing on. Increased WC was defined as $>102 \mathrm{~cm}$ and $>88 \mathrm{~cm}$ for men and women, respectively (21). Age, gender and clinical information including cancer treatment and stage were derived from the NCR. Educational level was derived from the questionnaire distributed in 2013.

\section{Health-Related Quality Of Life (HRQL)}

The validated European Organization for Research and Treatment of Cancer - Quality of Life Questionnaire (EORTC-QLQ)-C30 was used to assess HRQL (22). As the previous research showed that obesity among CRC patients was mainly associated with functioning scales and more symptoms of fatigue $(10,23)$ and to prevent spurious findings, only functioning scales (i.e., physical, emotional, social, cognitive, and role functioning), fatigue, and global health status were included in the analyses. All items were scored on a 4-point Likert scale ranging from "not at all" to "very much", except for the items regarding global health status which were scored from 1 (very poor) to 7 (excellent). All scores were linearly transformed to a 1-100 scale. Higher scores on functioning and global health status represent better functioning, while a higher score on fatigue symptoms correspond to more fatigue.

\section{Statistical Analyses}

Differences in baseline characteristics between CRC patients with normal weight, overweight or obesity were assessed using one-way ANOVA (for continuous variables) and $\chi 2$ analyses (for categorical variables). Similarly, differences in mean HRQL scores according to BMI categories and WC were assessed with one-way ANOVA or independent-samples $t$-test. The interaction between gender ${ }^{*}$ BMI on HRQL was tested in adjusted linear regression models; similarly the interaction between gender*WC was tested. Both interaction terms were not significant and omitted in further analyses. Also, the interaction effect of $\mathrm{BMI}^{*} \mathrm{WC}$ on HRQL was tested. In case the term was not significant, both BMI and WC were included in the model to test for their independent effect; if this interaction term was significant, results for the outcomes were stratified by BMI. A significant interaction between $\mathrm{BMI}^{*} \mathrm{WC}$ was observed for fatigue and global health status. Four multivariable linear regression models were constructed. Both the association of BMI, not adjusted for WC, with HRQL (Model 1) and the association of WC, not adjusted for BMI, with HRQL were assessed (Model 2). For those outcomes where no interaction between BMI and WC was observed, Model 3 was constructed in which the association of both BMI and WC with HRQL was assessed. As the interaction between BMI and WC was significant for fatigue and global health status, results were stratified for normal, underweight, and obese CRC survivors (Model 4). All models were adjusted for confounding factors determined a priori: age, sex, educational level, time since cancer diagnosis, cancer stage, and type of treatment.

A $p$-value $<0.05$ was regarded as statistically significant. In order to prevent multiple testing and associated type 1 errors, all $p$-values $<0.01$ were also shown. All analyses were conducted using the Statistical Package for Social Sciences (SPSS) version 17.0 (IBM).

\section{Results}

\section{Characteristics of the Study Population}

Of the 1,625 CRC survivors who were invited in August 2013, 1,111 (68\%) were included (Fig. 1). Nonrespondents did not differ regarding gender, time since cancer diagnosis or cancer treatment as compared to respondents. Nonrespondents were slightly younger (69.4 \pm 10.7 vs. $70.7 \pm 9.2 \mathrm{yr})$ and differed regarding cancer stage at diagnosis $(27 \%$ vs. $31 \%$ with stage I disease). Respondents with unknown weight, height, WC or with underweight $(n=48)$ did not differ regarding time since diagnosis, cancer treatment or stage, but were slightly older ( $75 \pm 10$ vs. $70 \pm 9 \mathrm{yr}$ ) and differed regarding gender ( $62 \%$ vs. $42 \%$ female) as compared to the full sample $(n=1,111)$. Among the 1,111 included CRC survivors, $34 \%$ had a normal weight, $49 \%$ were overweight and $17 \%$ were obese. The majority of overweight $(66 \%)$ and obese patients $(56 \%)$ were male as compared to $48 \%$ in the normal weight group $(p<0.01)$. No differences were found regarding age, educational level, time since diagnosis, received cancer treatment, and cancer stage between the different BMI categories (Table 1). In total, 493 (44\%) CRC survivors had increased WC which differed according to BMI category ( $p<0.01$, Fig. 2$)$. Twelve percent of normal weight survivors had an increased WC, whereas $49 \%$ of overweight and $11 \%$ of obese survivors had a normal WC. The correlation between waist and BMI was $r=0.57$.

\section{Health-Related Quality of Life}

Patients with increased WC reported worse physical functioning and higher fatigue scores than those with 
Table 1. Sociodemographic and clinical characteristics of the study population in different BMI categories.

\begin{tabular}{|c|c|c|c|c|}
\hline & $\begin{array}{c}\text { Normal weight } n=377 \text { (34\%) } \\
n(\%) \text { or mean } \pm \text { SD }\end{array}$ & $\begin{array}{l}\text { Overweight } n=546(49 \%) \\
\quad n(\%) \text { or mean } \pm \text { SD }\end{array}$ & $\begin{array}{l}\text { Obesity } n=188(17 \%) \\
n(\%) \text { or mean } \pm S D\end{array}$ & $P$-value \\
\hline Male & $181(48)$ & $360(66)$ & $105(56)$ & $<0.01$ \\
\hline Age (yr) & $71 \pm 9$ & $71 \pm 9$ & $70 \pm 9$ & 0.60 \\
\hline $\mathrm{BMI}\left(\mathrm{kg} / \mathrm{m}^{2}\right)$ & $23 \pm 2$ & $27 \pm 1$ & $33 \pm 5$ & $<0.01$ \\
\hline WC (cm) & $86 \pm 12$ & $98 \pm 11$ & $109 \pm 14$ & $<0.01$ \\
\hline$n(\%)$ increased $W C^{a}$ & $46(12)$ & $279(51)$ & $168(89)$ & $<0.01$ \\
\hline Time since diagnosis (yr) & $8 \pm 3$ & $8 \pm 3$ & $8 \pm 3$ & 0.84 \\
\hline \multicolumn{5}{|l|}{ Educational level $^{\mathrm{b}}$} \\
\hline Low & $34(9)$ & $63(12)$ & $29(16)$ & 0.09 \\
\hline Medium & $232(62)$ & $350(64)$ & $115(63)$ & \\
\hline High & $108(29)$ & $131(24)$ & $40(22)$ & \\
\hline \multicolumn{5}{|l|}{ Cancer stage } \\
\hline 1 & $122(32)$ & $172(32)$ & $57(30)$ & 0.51 \\
\hline$\|$ & $139(37)$ & $174(32)$ & $60(32)$ & \\
\hline III & $93(25)$ & $172(32)$ & $62(33)$ & \\
\hline IV & $11(3)$ & $13(2)$ & $5(3)$ & \\
\hline Unknown & $12(3)$ & $15(3)$ & $4(2)$ & \\
\hline Surgery & $374(99)$ & $544(100)$ & $187(99)$ & $\mathrm{n} / \mathrm{a}$ \\
\hline Chemotherapy & $97(26)$ & $176(32)$ & $59(31)$ & 0.09 \\
\hline Radiotherapy & $126(33)$ & $187(34)$ & $57(30)$ & 0.61 \\
\hline
\end{tabular}

ancreased waist circumference $>102 \mathrm{~cm}$ (male) and $>88 \mathrm{~cm}$ (female).

${ }^{b}$ Education levels included the following categories: low $=$ no/primary school; medium = lower general secondary education/vocational training; or high = preuniversity education/high vocational training/university.

$\mathrm{n} / \mathrm{a}$ no valid $p$-value could be calculated because low counts in cells without surgery.

normal WC, for all BMI categories (Table 2). Moreover, patients with a normal BMI and increased WC had worse role and emotional functioning and poorer global health status scores than those with normal BMI and normal WC. Additionally, patients with overweight and increased vs. normal WC reported worse role functioning. CRC survivors with obesity and increased WC reported worse emotional functioning as compared to those with normal WC (Table 2). Survivors with normal weight, overweight, and obesity but normal WC reported similar HRQL scores.

Multivariable linear regression models showed that being obese, but not overweight, vs. normal weight was significantly associated with lower scores on all functioning scales, a lower global health status and a higher level of fatigue (Table 3, Model 1). Similarly increased WC vs.

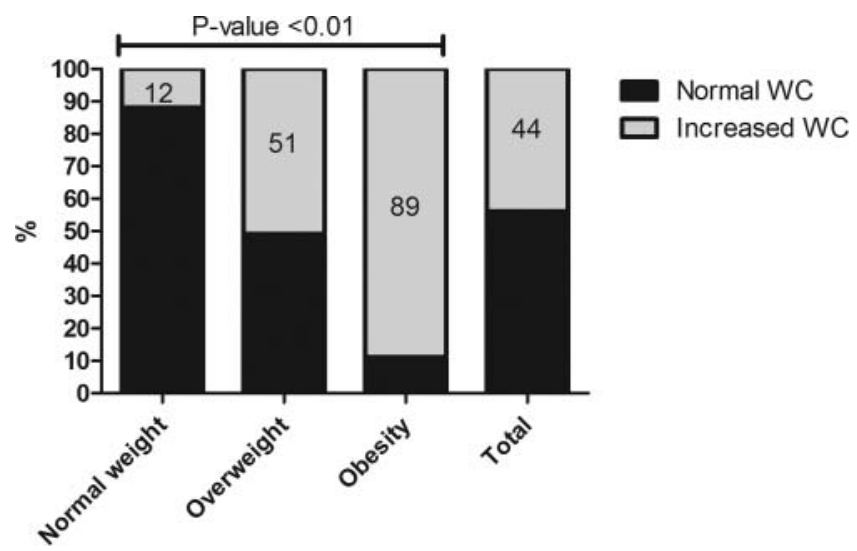

Figure 2. Percentage of normal and increased WC according to BMI categories. normal WC was associated with lower scores on all functioning scales, a lower global health status and more fatigue (Table 3, Model 2). After assessing the association of both BMI and WC with HRQL (Table 3, Model 3), $\mathrm{BMI}$ and waist were independently associated with worse physical and role functioning. Increased vs. normal WC, but not BMI was associated with worse emotional functioning (beta $=-2.7 ; 95 \%$ CI: $-5.3 /-0.1$ ). Moreover, being obese vs. normal weight, but not WC, was associated with worse cognitive and social functioning. As the association of WC on global health status and fatigue differed across separate BMI categories, results were stratified (Table 3, Model 4). Only survivors with normal weight, but not overweight and obesity, and increased WC scored significantly lower on global health status compared to survivors a normal WC with (beta $=-6.1$; 95\% CI: -11.7/-0.4). Normal weight and obese CRC survivors with increased WC reported higher fatigue scores $($ beta $=10.6 ; 95 \%$ CI:3.3/17.8 and beta $=13.7$; 95\% CI:1.7/25.7, respectively) compared to CRC survivors with a normal WC.

\section{Discussion}

In the present study, $66 \%$ of CRC survivors had excess weight and $44 \%$ had increased WC. Both increased BMI and increased WC were associated with worse functioning scores and more symptoms of fatigue. Moreover, $\mathrm{WC}$ and BMI were independently associated with lower physical- and role functioning. In addition, increased WC was associated with lower global health status among patients with normal weight and with increased 
Table 2. HRQL scores according to BMI and WC groups.

\begin{tabular}{|c|c|c|c|c|c|c|}
\hline & \multicolumn{6}{|c|}{ BMI } \\
\hline & \multicolumn{2}{|c|}{ Normal } & \multicolumn{2}{|c|}{ Overweight } & \multicolumn{2}{|c|}{ Obesity } \\
\hline & $\begin{array}{c}\text { Normal WC } \\
N=331\end{array}$ & $\begin{array}{c}\text { Increased WC } \\
N=46\end{array}$ & $\begin{array}{c}\text { Normal WC } \\
N=267\end{array}$ & $\begin{array}{c}\text { Increased WC } \\
N=279\end{array}$ & $\begin{array}{c}\text { Normal WC } \\
N=20\end{array}$ & $\begin{array}{c}\text { Increased WC } \\
N=168\end{array}$ \\
\hline Physical Functioning* & $86 \pm 18$ & $72 \pm 20^{b}$ & $86 \pm 17$ & $80 \pm 18^{b}$ & $85 \pm 19$ & $73 \pm 22^{\mathrm{a}}$ \\
\hline Role Functioning ${ }^{*}$ & $86 \pm 23$ & $79 \pm 24^{\mathrm{a}}$ & $87 \pm 21$ & $81 \pm 27^{\mathrm{a}}$ & $86 \pm 20$ & $74 \pm 30$ \\
\hline Emotional Functioning* & $89 \pm 16$ & $84 \pm 17^{\mathrm{a}}$ & $90 \pm 15$ & $88 \pm 17$ & $92 \pm 14$ & $84 \pm 21^{\mathrm{a}}$ \\
\hline Cognitive Functioning ${ }^{*}$ & $89 \pm 18$ & $89 \pm 15$ & $87 \pm 19$ & $87 \pm 18$ & $84 \pm 22$ & $83 \pm 22$ \\
\hline Social Functioning ${ }^{*}$ & $91 \pm 20$ & $89 \pm 18$ & $90 \pm 20$ & $89 \pm 20$ & $92 \pm 17$ & $83 \pm 25$ \\
\hline Global Health status ${ }^{*}$ & $80 \pm 17$ & $73 \pm 19^{a}$ & $80 \pm 17$ & $79 \pm 16$ & $81 \pm 15$ & $72 \pm 20$ \\
\hline Fatigue $^{\#}$ & $17 \pm 21$ & $31 \pm 27^{b}$ & $17 \pm 20$ & $21 \pm 22^{\mathrm{a}}$ & $15 \pm 18$ & $28 \pm 25^{\mathrm{a}}$ \\
\hline
\end{tabular}

Independent-samples $t$-test between normal and increased WC within each BMI group.

*Higher scores represent better functioning or better global health status.

"Higher scores represent a higher level of fatigue.

${ }^{\mathrm{a}} p<0.05$.

${ }^{\mathrm{b}} p<0.01$.

fatigue among normal and obese individuals. These results suggest that $\mathrm{WC}$, besides $\mathrm{BMI}$, should be considered in future studies assessing HRQL among CRC survivors. Furthermore, weight reduction trials should not only focus on general weight loss but also investigate the effect of nutrition and physical activity on the loss of abdominal fat.

As far as we know, no studies in CRC survivors focused on the association between WC and HRQL. Previous studies mostly assessed the association between WC and (disease-specific) survival showing a poorer (disease-specific) survival with increased WC $(16,24)$. In our study, both BMI and WC were associated with HRQL. Moreover, WC was associated with worse physical, role, and emotional functioning, regardless of BMI. In addition, patients with obesity or overweight but with a normal WC had the same HRQL scores as compared to patients with normal weight and normal WC (Table 2), which remained apparent in multivariable analyses (data not shown). This indicates that WC might be stronger associated with HRQL than BMI. This is in accordance with studies on complications and survival of CRC patients, where WC was found to be a stronger predictor than BMI $(16-18,25)$.

If $\mathrm{WC}$ can be seen as a proxy for abdominal fat, our results are in accordance with previous literature. Although not studied among cancer patients, several studies showed an association between abdominal obesity and poorer HRQL $(14,26,27)$. Our results suggest that the so-called "metabolically unhealthy obese" (i.e., those with overweight/obesity and an unfavorable metabolic profile including more abdominal fat) have worse outcomes than the so-called "metabolically healthy obese" (i.e., those with overweight/obesity and a favorable metabolic profile). Several studies suggest that the metabolically healthy obese might be at lower risk for cardiovascular disease and mortality as compared to the metabolically unhealthy obese $(28,29)$. Adipose tissue has previously been shown to contribute to inflammation, insulin resistance and dyslipidemia, which in turn can promote the development of chronic diseases (30) and impair HRQL. Future studies should therefore investigate the mechanisms behind the development of metabolically healthy vs. unhealthy obesity and whether changes in lifestyle can influence the amount of abdominal fat. Weight reduction trials in cancer patients should not only focus on weight reduction in general but especially focus on the effects of nutrition and physical activity on abdominal fat reduction which can be measured by WC.

Strengths of the study are the large study population and the population-based character. This study also has some limitations. First, the BMI and WC data were collected half a year before the collection of the HRQL data. However, we do not expect large changes in BMI, WC and HRQL within half a year in this population of longterm CRC survivors. Unfortunately, no information on comorbid conditions, socioeconomic deprivation, and physical activity was available which are known to have a significant impact on HRQL $(31,32)$. However, we did adjust for educational level, which was used as a proxy for socioeconomic deprivation. Due to the lack of data on comorbidity and physical activity and due to the cross-sectional study design, we cannot draw conclusions on causality regarding the association between WC, BMI, and HRQL. Moreover, body height and body weight were self-reported. Previous research shows high correlations between self-reported and objectively assessed BMI, with the exception of elderly ( $>60 \mathrm{yr}$ ) who often over-report their height resulting in an underreported BMI (33). This might have led to an underestimation of the effect of BMI. In addition, WC was self-assessed which did not differ from professionally measured WC in a previous study (34). However, in some groups, 


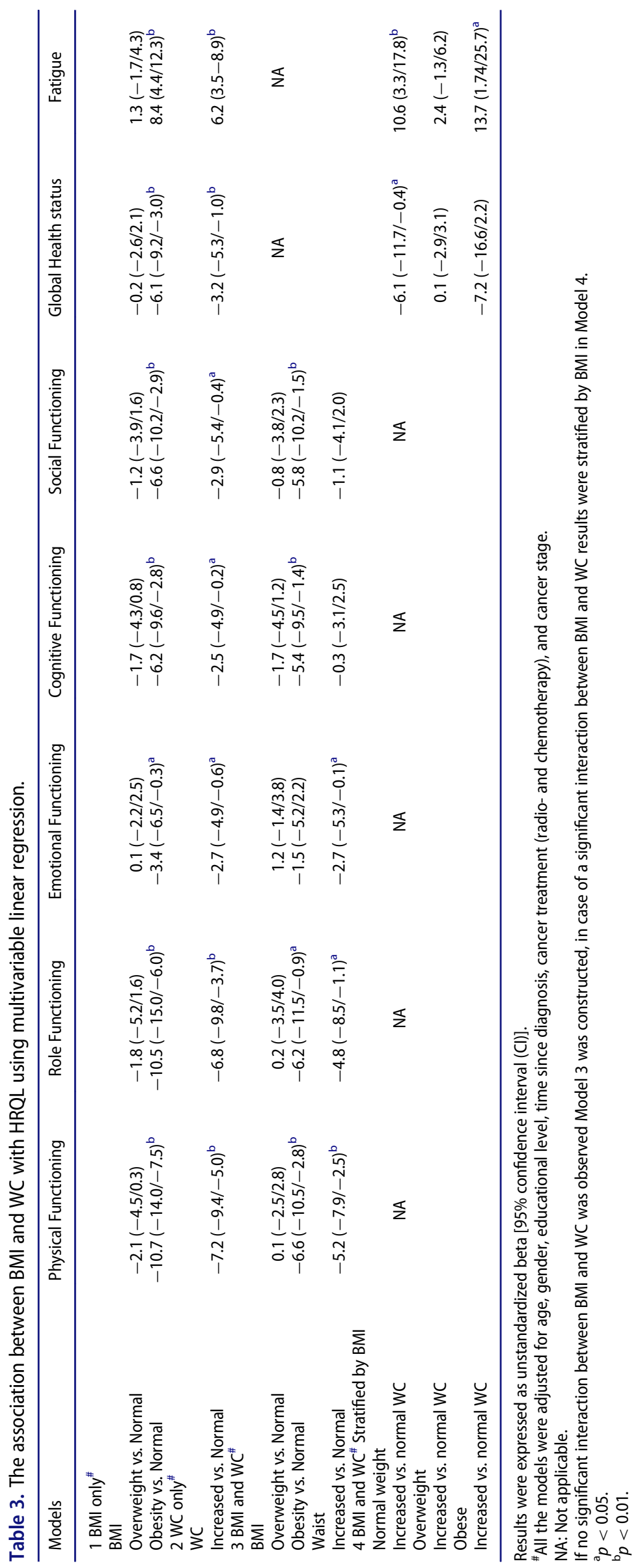


mainly obese men, the false-negative rate of self-measurements exceeded $20 \%$ (34). Only $9 \%$ of our sample consisted of obese men; therefore, the influence of selfassessed WC might be negligible. Moreover, WC is an indirect way of estimating abdominal fat. More direct measurements like Computed Tomography (CT) scans might be more reliable but are expensive and not viable in clinical practice (35). However, WC was found to be a valid surrogate marker of intra-abdominal fat (36).

\section{Conclusion}

This study showed that higher BMI and increased WC are both associated with worse functioning, lower global health status and more symptoms of fatigue. Moreover, increased WC was associated with lower physical, role, and emotional functioning, regardless of BMI. Future research on HRQL among CRC survivors should take both BMI and WC into account. Furthermore, weight reduction trials should not only focus on weight loss in general but also investigate the effect of nutrition and physical activity on the reduction of abdominal fat.

\section{Funding}

Data collection for this study was funded by the Netherlands Comprehensive Cancer Organisation; the Center of Research on Psychology in Somatic diseases (CoRPS), Tilburg University, The Netherlands; an investment subsidy (\#480-08-009) of the Netherlands Organization for Scientific Research (The Hague, The Netherlands) and by a VENI grant (\#451-10-041) from the Netherlands Organization for Scientific Research (The Hague, The Netherlands) awarded to Floortje Mols. M.J. L. Bours is partly supported by a grant from the Stichting Alpe d'HuZes within the research program 'Leven met kanker' of the Dutch Cancer Society (Grant No. UM-2012-5653), and partly by a grant from Kankeronderzoekfonds Limburg (part of Health Foundation Limburg; Grant No. 00005739). The funding sources were neither involved in the collection, interpretation, and analysis of the data, nor in the decision for the writing and submission of this report for publication.

\section{Conflict of interest statement}

The authors declare that they have no conflict of interest.

\section{Acknowledgments}

The authors thank all survivors and their doctors for their participation in the study. Special thanks to Dr. M van Bommel for her availability as an independent advisor and willingness to answer survivors' queries. In addition, we thank the following hospitals for their co-operation: Amphia Hospital (Breda), Bernhoven Hospital (Veghel and Oss), Catharina Hospital (Eindhoven), Elkerliek Hospital (Helmond), Jeroen Bosch Hospital ('s-Hertogenbosch), Maxima Medical Center
(Eindhoven and Veldhoven), St Anna Hospital (Geldrop), St Elisabeth Hospital (Tilburg), Twee Steden Hospital (Tilburg and Waalwijk), and VieCuri Hospital (Venlo and Venray).

\section{References}

1. Ferlay J, Soerjomataram I, Dikshit R, Eser S, Mathers C, et al.: Cancer incidence and mortality worldwide: sources, methods and major patterns in GLOBOCAN 2012. Int J Cancer 136, E359-E386, 2015.

2. Arnold M, Sierra MS, Laversanne M, Soerjomataram I, Jemal A, et al.: Global patterns and trends in colorectal cancer incidence and mortality. Gut 66, 683-691, 2017.

3. Ait Ouakrim D, Pizot C, Boniol M, Malvezzi M, Boniol M, et al.: Trends in colorectal cancer mortality in Europe: retrospective analysis of the WHO mortality database. BMJ 351, h4970, 2015.

4. Jansen L, Koch L, Brenner H, and Arndt V: Quality of life among long-term $(>/=5$ years) colorectal cancer survivors-systematic review. Eur J Cancer 46, 2879-2888, 2010.

5. Marventano S, Forjaz M, Grosso G, Mistretta A, Giorgianni $G$, et al.: Health related quality of life in colorectal cancer patients: state of the art. BMC Surg 13 (Suppl 2), S15, 2013.

6. Den Oudsten BL, Traa MJ, Thong MS, Martijn H, De Hingh $\mathrm{IH}$, et al.: Higher prevalence of sexual dysfunction in colon and rectal cancer survivors compared with the normative population: a population-based study. Eur J Cancer 48, 3161-3170, 2012.

7. Blanchard CM, Stein K, and Courneya KS: Body mass index, physical activity, and health-related quality of life in cancer survivors. Med Sci Sports Exerc 42, 665-671, 2010.

8. Sapp AL, Trentham-Dietz A, Newcomb PA, Hampton JM, Moinpour CM, et al.: Social networks and quality of life among female long-term colorectal cancer survivors. Cancer 98, 1749-1758, 2003.

9. Trentham-Dietz A, Remington PL, Moinpour CM, Hampton JM, Sapp AL, et al.: Health-related quality of life in female long-term colorectal cancer survivors. Oncologist 8, 342-349, 2003.

10. Vissers PA, Thong MS, Pouwer F, Creemers GJ, Slooter GD, et al.: Prospectively measured lifestyle factors and BMI explain differences in health-related quality of life between colorectal cancer patients with and without comorbid diabetes. Support Care Cancer 24, 2591-2601, 2016.

11. Rodriguez JL, Hawkins NA, Berkowitz Z, and Li C: Factors associated with health-related quality of life among colorectal cancer survivors. Am J Prev Med 49, S518-S527, 2015.

12. Leitzmann MF, Moore SC, Koster A, Harris TB, Park Y, et al.: Waist circumference as compared with body-mass index in predicting mortality from specific causes. PLoS One 6, e18582, 2011.

13. Song M, Hu FB, Spiegelman D, Chan AT, Wu K, et al.: Long-term status and change of body fat distribution, and risk of colorectal cancer: a prospective cohort study. Int J Epidemiol 45, 871-883, 2016.

14. Ford ES and Li C: Metabolic syndrome and healthrelated quality of life among U.S. adults. Ann Epidemiol 18, 165-171, 2008.

15. Pouliot MC, Despres JP, Lemieux S, Moorjani S, Bouchard $\mathrm{C}$, et al.: Waist circumference and abdominal sagittal 
diameter: best simple anthropometric indexes of abdominal visceral adipose tissue accumulation and related cardiovascular risk in men and women. Am J Cardiol 73, 460-468, 1994.

16. Haydon AM, Macinnis RJ, English DR, and Giles GG: Effect of physical activity and body size on survival after diagnosis with colorectal cancer. Gut 55, 62-67, 2006.

17. Prizment AE, Flood A, Anderson KE, and Folsom AR: Survival of women with colon cancer in relation to precancer anthropometric characteristics: the Iowa Women's Health Study. Cancer Epidemiol Biomarkers Prev 19, 2229-2237, 2010.

18. Balentine CJ, Robinson CN, Marshall CR, Wilks J, Buitrago W, et al.: Waist circumference predicts increased complications in rectal cancer surgery. J Gastrointest Surg 14, 1669-1679, 2010.

19. van de Poll-Franse LV, Horevoorts N, van Eenbergen M, Denollet J, Roukema JA, et al.: The Patient Reported Outcomes Following Initial treatment and Long term Evaluation of Survivorship registry: scope, rationale and design of an infrastructure for the study of physical and psychosocial outcomes in cancer survivorship cohorts. Eur J Cancer 47, 2188-2194, 2011.

20. Husson O, Mols F, Ezendam NP, Schep G, and van de Poll-Franse LV: Health-related quality of life is associated with physical activity levels among colorectal cancer survivors: a longitudinal, 3-year study of the PROFILES registry. J Cancer Surviv 9, 472-480, 2015.

21. World Health Organization: Waist circumference and waist-hip ratio: report of a WHO expert consultation. Geneve, 8-11 December 2008, p 1-39

22. Aaronson NK, Ahmedzai S, Bergman B, Bullinger M, Cull A, et al.: The European Organization for Research and Treatment of Cancer QLQ-C30: a quality-of-life instrument for use in international clinical trials in oncology. $J$ Natl Cancer Inst 85, 365-376, 1993.

23. Schlesinger S, Walter J, Hampe J, von Schonfels W, Hinz S, et al.: Lifestyle factors and health-related quality of life in colorectal cancer survivors. Cancer Causes Control 25, 99-110, 2014.

24. Fedirko V, Romieu I, Aleksandrova K, Pischon T, Trichopoulos D, et al.: Pre-diagnostic anthropometry and survival after colorectal cancer diagnosis in Western European populations. Int J Cancer 135, 1949-1960, 2014.

25. Rickles AS, Iannuzzi JC, Mironov O, Deeb AP, Sharma A, et al.: Visceral obesity and colorectal cancer: are we missing the boat with BMI? J Gastrointest Surg 17, 133-143; discussion p 143, 2013.
26. Wu S, Wang R, Jiang A, Ding Y, Wu M, et al.: Abdominal obesity and its association with health-related quality of life in adults: a population-based study in five Chinese cities. Health Qual Life Outcomes 12, 100, 2014.

27. Han TS, Tijhuis MA, Lean ME, and Seidell JC: Quality of life in relation to overweight and body fat distribution. Am J Public Health 88, 1814-1820, 1998.

28. Ortega FB, Lee DC, Katzmarzyk PT, Ruiz JR, Sui X, et al.: The intriguing metabolically healthy but obese phenotype: cardiovascular prognosis and role of fitness. Eur Heart $J$ 34, 389-397, 2013.

29. Ogorodnikova AD, Kim M, McGinn AP, Muntner P, Khan U, et al.: Incident cardiovascular disease events in metabolically benign obese individuals. Obesity (Silver Spring) 20, 651-659, 2012.

30. Gutierrez DA, Puglisi MJ, and Hasty AH: Impact of increased adipose tissue mass on inflammation, insulin resistance, and dyslipidemia. Curr Diab Rep 9, 26-32, 2009.

31. Aarts MJ, Mols F, Thong MS, Louwman MW, Coebergh JW, et al.: Long-term prostate cancer survivors with low socioeconomic status reported worse mental healthrelated quality of life in a population-based study. Urology 76, 1224-1230, 2010.

32. Vissers PA, Thong MS, Pouwer F, Zanders MM, Coebergh JW, et al.: The impact of comorbidity on Health-Related Quality of Life among cancer survivors: analyses of data from the PROFILES registry. J Cancer Surviv 7, 602-613, 2013.

33. Kuczmarski MF, Kuczmarski RJ, and Najjar M: Effects of age on validity of self-reported height, weight, and body mass index: findings from the Third National Health and Nutrition Examination Survey, 1988-1994. J Am Diet Assoc 101, 28-34; quiz 35-6, 2001.

34. Carranza Leon BG, Jensen MD, Hartman JJ, and Jensen TB: Self-measured vs. professionally measured waist circumference. Ann Fam Med 14, 262-266, 2016.

35. Malietzis G, Aziz O, Bagnall NM, Johns N, Fearon KC, et al.: The role of body composition evaluation by computerized tomography in determining colorectal cancer treatment outcomes: a systematic review. Eur J Surg Oncol 41, 186-196, 2015.

36. Borruel S, Molto JF, Alpanes M, Fernandez-Duran E, Alvarez-Blasco F, et al.: Surrogate markers of visceral adiposity in young adults: waist circumference and body mass index are more accurate than waist hip ratio, model of adipose distribution and visceral adiposity index. PLoS One 9, e114112, 2014. 